\title{
TRANSFORMASI SAMPAH PLASTIK BERBASIS DESTILASI PANEL SURYA
}

\author{
Fakhrur Ramadani ${ }^{1}$, Hanif Alwan Mumtaz ${ }^{2}$, Muhammad Faizal Fahmi $^{3}$, Muhammad \\ Rustamaji ${ }^{4}$ \\ ${ }^{1,2}$ Fakultas Hukum Universitas Sebelas Maret, Surakarta \\ ${ }^{3}$ Fakultas Teknik Universitas Sebelas Maret, Surakarta \\ ${ }^{4}$ Dosen Fakultas Hukum Universitas Sebelas Maret, Surakarta \\ fakhrurramadani@gmail.com, hanif.alwanmumtaz@gmail.com, faizalfahmi2000@gmail.com, \\ hatchi_ajie@yahoo.com
}

\begin{abstract}
Abstrak
Plastik sudah menjadi bagian kehidupan sehari-hari manusia dan tidak dapat dipisahkan dari gaya hidup praktis masa kini. Akan tetapi penggunaan plastik yang berlebihan dapat menimbulkan dampak negatif pada lingkungan. Salah satu jenis sampah yang menjadi perhatian utama adalah sampah plastik. Langkah alternatif untuk menangani sampah plastik yang saat ini banyak diteliti dan dikembangkan adalah mengkonversikan sampah plastik menjadi BBM sintetis. Problematika akibat sampah plastik inilah yang kemudian dibedah melalui metode Participatory Rural Appraisal untuk ditemukan solusinya. Melalui rancang bangun alat berbasis metode destilasi tenaga surya inilah kelompok Program Kreativitas Mahasiswa berhasil mentransformasikan sampah plastik menjadi BBM sintetis. Alat ini menggunakan tenaga surya yang diubah menjadi listrik sehingga menghasilkan energi panas yang dapat mengubah sampah plastik menjadi bahan bakar minyak sintetis. Sampah plastik yang dimasukkan kedalam alat akan mengalami proses destilasi sehingga menghasilan bahan bakar sintetis setarapremium dan solar. Alat ini merupakan langkah solutif untuk mengubah sampah menjadi produk yang berdaya guna, utamanya pada berbagai macam mesin yang memerlukan bahan bakar minyak.
\end{abstract}

Kata kunci: sampah plastik, BBM sintetis, destilasi tenaga surya

\section{PENDAHULUAN}

Plastik sudah menjadi bagian kehidupan sehari-hari manusia dan tidak dapat dipisahkan dari gaya hidup praktis masa kini. Akan tetapi, pengunaan plastik yang berlebihan tentu saja dapat menimbulkan dampak negatif pada lingkungan. Kemasan plastik sudah mendominasi industri makanan di Indonesia dan kemasan luwes (fleksibel) menempati porsi $80 \%$. Jumlah plastik yang digunakan untuk mengemas, menyimpan dan membungkus makanan mencapai 53\% khusus untuk kemasan luwes, sedangkan kemasan kaku sudah mulai banyak digunakan untuk minuman (Nasution, 2019: 97). Berdasarkan realitas dan data tersebut, maka dapat dikemukakan bahwa penggunaan plastik seakan sudah tidak bisa lagi dihindari. Oleh karena itu, diperlukan Lingkungan Hidup dan Bencana 616 
suatu tindakan nyata untuk meminimalisir dampak buruk dari sampah plastik yang bertambah banyak dari waktu ke waktu. Mengingat sifat plastik yang tidak mudah diurai oleh alam, maka diperlukan suatu metode yang tepat untuk mengolahsampah plastik bahkan mengubahnya menjadi sumber energi baru. Pengelolaan sampah inilah yang merupakan kegiatan yang secara sistematis dan berkesinambungan meliputi pengurangan dan penanganan sampah (Wardi, 2011: 167).

Salah satu langkah yang dapat ditempuh guna mengubah sampah plastik menjadi sumber energi baru yaitu dengan memanfaatkan energi panas matahari. Energi surya merupakan energi yang potensial dikembangkan pemanfaatannya di Indonesia. Hal demikian dikarenakan Indonesia merupakan negara yang terletak di wilayah khatulistiwasehingga sepanjang tahun disinari matahari. Intensitas sinar matahari demikian bahkan dirasakan relatif tinggiterutama pada daerah timur Indonesia.

Berdasarkan pembacaan literatur mengenai potensi energi surya, diketahui bahwa energi matahari yang dapat dioptimalkan untuk seluruh daratan Indonesia yang mempunyai luas kurang lebih 2 juta $\mathrm{km}^{2}$ adalah sebesar $5,10 \mathrm{~mW}$ atau $4,8 \mathrm{kWh} / \mathrm{m}^{2}$ /hari atau setara dengan $112.000 \mathrm{gWp}$ yang didistribusikan (Hasan, 2012: 170-171). Oleh karena itu, energi matahari yang melimpah dapat dimanfaatkan guna mengurangi pencemaran sampah plastik sekaligus menghasilkan sumber energi baru berbasis sampah plastik. Sampah plastik ini diproyeksikan menjadi bahan bakar minyak alternatif (BBM Sintetis) yang dapat dimanfaatkan masyarakat dalam aktivitas kesehariannya.

Guna mewujudkan gagasan sebelumnya, maka diwujudkanlah rancang bangun alat pengubah sampah plastik

menjadi bahan bakar minyak alternatif yang dinamakan 'Aplas Jadul'. Alat ini memanfaatkan energi panas matahari yang diubah menjadi energi listrik melalui panel surya, untuk selanjutnya dioptimalkan guna menghasilkan BBM Sintetis berbahan sampah plastik. Pemanfaatan energi matahari inilah yang menjadi pembeda (novelty) dengan alat pengolah sampah plastik yang banyak beredar di masyarakat namun tanpa menenggang keramahan bagi lingkungan. Eksistensi alat ini diharapkan dapat berperan melestarikan lingkungan karena selain mengurangi sampah plastik, dihasilkan pula sumber energi baru berwujud BBM sintetis berbahan sampah plastik. Manfaat lain yang dihasilkan dari produk ini adalah munculnya inovasi rancang bangun alat pengolah sampah plastik yang ramah lingkungan tanpa menghasilkan emisi gas buang saat pemprosesan sampah plastik menjadi BBM Sintetis.

Berdasarkan diskusi tim bersama ketua Bank Sampah Selo Beraksi Desa Pojok, Ibu Agustina Dyah Indriyani, terdapat permasalahan yang seharusnya segera diatasi yaitu belum maksimalnya pemanfaatan sampah plastik yang ada di Bank Sampah Beraksi Desa Pojok. Oleh karena itu, diperlukan inovasi untuk memaksimalkan pengolahan sampah plastik di bank sampah tersebut. Kurangnya kesadaran masyarakat Desa Pojok untuk menyetorkan sampah ke bank sampah juga menjadi permasalahan yang harus diatasi. Cara yang tepat untuk mengatasi sampah plastik yang semakin menggunung yaitu dengan mengubahnya menjadi bahan bakar minyak. Tidak hanya mengurangi sampah plastik namun juga dapatmenghemat penggunaan bahan bakar minyak dari alam.

Bahan bakar sintetis hasil pengolahan ini memiliki beberapa manfaat 
bagi mitra, dari faktor ekonomi, sosial, maupun lingkungan. Berdasarkan pengamatan kami, sebagian besar masyarakat Desa Pojok memerlukan bahan bakar minyak dalam melakukan aktivitas sehari-hari, seperti menghidupkan alat diesel, traktor, memasak, alat penerangan, dan masih banyak lagi. Oleh karena itu, dengan adanya bahan bakar minyak sintetis ini diharapkan dapat membantu masyarakat Desa Pojok dalam memenuhi kebutuhan bahan bakar minyak. Bahan bakar minyak sintetis ini menjadi solusi bagi permasalahan yang dihadapi masyarakat Desa Pojok, hanya dengan "Nabung Sampah" mereka bisa mendapatkan bahan bakar minyak untuk memenuhi kebutuhan mereka. Upaya ini diharapkan dapat berperan efektif dan efisien dalam mengolah sampah plastik, meningkatkan kesadaran masyarakat Desa Pojok untuk memilah sampah sesuai kriterianya, sekaligus menyejahterakan masyarakat Desa Pojok melalui tercukupinya kebutuhan bahan bakar minyak.

\section{METODE}

\section{KERJASAMA MITRA}

Mata pencaharian masyarakat Desa Pojok, Tawangsari, Sukoharjo adalah buruh, karyawan swasta, wirausaha, dan petani, namun mayoritas masyarakat bekerja sebagai petani sehingga memerlukan berbagai alat yang digunakan untuk bertani. Masyarakat Desa Pojok juga membutuhkan bahan bakar minyak yang digunakan untuk melaksanakan aktivitas mereka, seperti menghidupkan alat diesel, alat traktor, dan alat lain yang mereka gunakan. Disisi lain juga terdapat bank sampah yang digunakan untuk menampung sampah-sampah di Desa Pojok yang bernama Bank Sampah Selo Beraksi. Permasalahan yang dihadapi bank sampah ini adalah belum memaksimalkan pengolahan sampah plastik yang ada di bank sampah ini. Bank Sampah Selo Beraksi merupakan sebuah wadah yang berguna untuk menampung sampah-sampah dari masyarakat Desa Pojok, Tawangsari, Sukoharjo, sampah yang ditampung disini bervariasi mulai dari sampah kertas sampai sampah plastik.

Sampah-sampah tersebut nantinya dimanfaatkan untuk diubah menjadi kerajinan tangan, tidak hanya itu sampahsampah di paguyuban ini juga dijual tanpa diolah terlebih dahulu. Berdasarkan permasalahan yang dihadapi paguyuban ini, maka kami menawarkan solusi yang dapat digunakan untuk mengoptimalkan pemanfaatan sampah plastik yang ada disini. Solusi tersebut adalah mengolah sampah plastik menjadi bahan bakar minyak sintetis. Alat pengolah sampah plastik menjadi bahan bakar minyak ini adalah alat yang dioperasikan menggunakan tenaga surya yang diharapkan dapat menghemat energi dalam mengolah sampah plastik.

Alat pengolah sampah plastik menjadi bahan bakar minyak sintetis bertenaga surya merupakan gagasan yang dapat menjawab permasalahan diatas. Alat ini memiliki beberapa keunggulan, diantaranya:

1. Alat ini berukuran kecil sehingga tidak memakan tempat dan mudah dipindahkan ke tempat yang kita inginkan.

2. Alat ini merupakan alat yang sederhana sehingga memudahkan dalam perawatan, mudah dalam penggantian dan mendapatkan spare part.

3. Alat ini dijalankan oleh panel surya yang merubah sinar matahari menjadi aliran listrik sehingga dapat

Lingkungan Hidup dan Bencana 618 
memperoleh aliran listik secara mandiri yang ramah lingkungan.

4. Alat ini merupakan alat yang mudah dalam pengoperasiannya sehingga memudahkan masyarakat dalam menjalankannya.

Dari beberapa keunggulan yang tersebut diatas, alat ini memberikan beberapa manfaat kepada mitra ditinjau dari beberapa aspek diantaranya:

1. Segi ekonomi

Peningkatan produktivitas anggota Bank Sampah Selo Beraksi berupa recycle sampah plastik menjadi bahan bakar minyak sintetis. Sampah plastik yang awalnya hanya diubah menjadi kerajinan kini anggota paguyuban ini dapat mengubah sampah plastik menjadi bahan bakar minyak sintetis sehingga meningkatkan produktivitas mitra. Manfaat ini tidak hanya dirasakan oleh anggota Bank Sampah Selo Beraksi saja, namun masyarakat Desa Pojok juga ikut merasakan dampak positif dari adanya alat pengubah sampah plastik bertenaga surya menjadi bahan bakar minyak sintesis ini, manfaat yang mereka rasakan adalah lebih menghemat biaya dalam hal mendapatkan bahan bakar untuk menjalankan alat-alat penunjang aktivitas sehari-hari mereka.

2. Segi kesehatan

Manfaat yang dirasakan masyarakat dari segi kesehatan berupa kondisi lingkungan yang bersih sehingga terciptanya kehidupan masyarakat yang sehat terhindar dari berbagai penyakit yang timbul karena sampah-sampah yang ada di lingkungan sekitar.

3. Segi sosial
Dengan adanya alat pengolah sampah plastik bertenaga surya menjadi bahan bakar minyak sintetis ini maka akan menghemat pengeluaran masyarakat, yang awalnya masyarakat harus mengeluarkan uang untuk membeli bahan bakar minyak setelah adanya alat ini maka masyarakat dapat menghemat pengeluaran karena masyarakat Desa Pojok dapat mendapatkan bahan bakar minyak sintetis secara gratis hanya dengan menyetorkan sampah plastik ke Bank Sampah Selo Beraksi. Hal ini tentunya mampu meningkatkan kondisi ekonomi masyarakat dan secara otomatis meningkatkan kondisi sosial masyarakat Desa Pojok.

Saat ini sudah banyak orang yang menciptakan alat pengolah sampah plastik menjadi bahan bakar minyak, sebagai contoh alat yang dikembangkan di Pasar Inis Kabupaten Purworejo, Jawa Tengah, di pasar ini terdapat alat pengubah sampah plastik menjadi bahan bakar minyak menggunakan tenaga api. Di lain tempat, alat semacam ini juga dikembangkan oleh mahasiswa D-3 Teknik Mesin Universitas Gadjah Mada, Yanditya Affan Almada, alat buatannya ini menggunakan bantuan tenaga listrik dalam mengoperasikan alat buatannya. Namun, kami memiliki sebuah gagasan untuk memodifikasi penemuan tersebut dengan menggunakan bantuan panel surya untuk mendapatkan energi yang akan digunakan untuk menjalankan alat ini. Hingga saat ini, belum ada yang menciptakan alat pengolah sampah plastik menjadi bahan bakar minyak sintetis dengan panel surya. Oleh karena itu, kami mengangkatnya sebagai tema dalam PKM-T dengan harapan inovasi baru yang diterapkan memiliki potensi HKI yang baik.

Lingkungan Hidup dan Bencana 
Kegiatan yang dilakukan bersama mitra berupa kegiatan penyuluhan tentang alat pengolah sampah plastik bertenaga surya menjadi bahan bakar sintetis, pelaksanaan penelitian dan pembuatan alat. Selanjutnya dilakukan evaluasi dan pengembangan terhadap alat yang dihasilkan, dan pada akhir kerjasama kami bermaksud menyumbangkan produk yang dihasilkan kepada mitra (Bank Sampah Selo Beraksi).

\section{TINJAUAN PUSTAKA}

\section{Panel Surya Sebagai Pengkonversi Energi}

Panel surya atau sel photovoltaic merupakan kumpulan dari beberapa sel surya yang saling berhubungan secara elektrik dan berkumpul pada suatu perangkat yang terstruktur. Sel surya yang terdapat di panel surya dapat mengkonversi energi cahaya matahari menjadi energi listrik. Sel surya ini terbuat dari potongan silikon yang sangat kecil, potongan silikon ini dilapisi bahan kimia khusus untuk membentuk dasar dari sel surya. Sel surya pada umumnya memiliki ketebalan minimum $0,3 \mathrm{~mm}$ yang terbuat dari irisan bahan semikonduktor dengan kutub positif dan negatif. Tiap sel surya biasanya menghasilkan tegangan $0,5 \mathrm{~V}$ (Raban, dkk, 2015: 1902). Sel surya adalah elemen aktif (semikonduktor) yang memanfaatkan efek fotovoltaik untuk mengubah energi surya menjadi energi listrik.

\section{Solar Charge Controller}

Solar charge controller merupakan sebuah rangkaian elektronik yang berfungsi mengatur proses pengisian baterai. Komponen ini berperan dalam proses mengatur pengisian arus listrik dari panel surya menujubaterai dan sebaliknya. Saat baterai tersisa $20 \%$ sampai $30 \%$, maka regulator akan memutuskan dengan beban. Regulator baterai berfungsi mengatur kelebihan pengisian baterai dan kelebihan tegangan pada panel surya. Manfaat lain dari alat ini juga untuk menghindari full discharge dan overloading serta memonitor suhu baterai. Kelebihan tegangan dan pengisian baterai berakibat buruk yaitu mengurangi umur baterai.

\section{Battery Solar Panel}

Baterai adalah obyek kimia penyimpan arus listrik (Irwansyah, dkk, 2013: 86). Energi listrik yang berada pada baterai dapat digunakan untuk mengisi ulang daya smartphone, senter, dan alat elektronik lainnya serta pada malam hari dan hari mendung dapat digunakan untuk menyalakan penerangan. Baterai tidak seratus persen efisien, beberapa energi hilang seperti panas dari reaksi kimia, selama charging dan discharging.

\section{Inverter}

Inverter adalah perangkat elektrik yang digunakan untuk mengubah arus listrik searah (DC) menjadi arus listrik bolak balik (AC) (Heri: 50). Inverter mengubah arus DC dari perangkat seperti baterai, panel surya / solar cell menjadi arus AC. Hal-hal yang perlu diperhatikan dalam memilih inverter adalah kapasitas beban dalam watt dan memilih inverter yang beban kerjanya mendekati dengan beban yang hendak digunakan, hal ini bertujuan agar efisiensi kerja yang maksimal. Pada alat rancangan tim ini menggunakan inverter 1000 watt.

\section{Modul Speed Control}

Modul speed control adalah rangkaian alat pengatur kecepatan putaran motor AC sehingga alat ini berfungsi untuk mengatur temperatur kecepatan motor AC, terang lampu ruangan, dan sebagainya. Alat ini juga dapat membatasi arus agar tidak

Lingkungan Hidup dan Bencana 620 
terjadi overload pada peralatan elemen. Modul speed control pada alat ini berfungsi sebagai pengatur besar kecilnya aliran listrik yang bersumber dari panel surya kemudian disalurkan pada kawat nikelin agar tidak terjadi kelebihan arus listrik.

\section{Kawat Nikelin}

Kawat nikelin merupakan kawat penghantar panas yang dibuat secara khusus untuk mengubah daya listik menjadi energi panas. Penggunaan kawat nikelin pada "Aplas Jadul" ini bertujuan untuk mengalirkan panas dari panel surya ke dalam tong sehingga dapat mengubah energi listrik menjadi energi panas. Kawat nikelin pada alat ini berfungsi sebagai penghantar panas untuk melelehkan sampah plastik yang ada di tong stainless steel. Kawat nikelin dapat menahan panas hingga suhu 1000 derajat celcius sehingga cocok digunakan pada alat ini.

7. Plastik

Dalam proses pembuatan rancang bangun suatu alat pengolah sampah plastik menjadi bahan bakar minyak sintetis berbasis tenaga surya ini diperlukan informasi mengenai sifat thermal dari berbagai jenis plastik. Sifat-sifat thermal yang penting adalah titik lebur (Tm), temperatur transisi ( $\mathrm{Tg}$ ) dan temperatur dekomposisi. Temperatur transisi adalah temperatur di mana plastik mengalami perengganan struktur sehingga terjadi perubahan dari kondisi kaku menjadi lebih fleksibel. Di atas titik lebur, plastik mengalami pembesaran volume sehingga molekul bergerak lebih bebas yang ditandai dengan peningkatan kelenturannya. Temperatur lebur adalah temperatur di mana plastik mulai melunak dan berubah menjadi cair. Temperatur dekomposisi merupakan batasan dari proses pencairan. Jika suhu dinaikkan di atas temperatur lebur, plastik akan mudah mengalir dan struktur akan mengalami dekomposisi. Data sifat thermal yang penting pada proses daur ulang plastik bisa dilihat pada Tabel 1 sebagai berikut:

Tabel 1. Data temperatur transisi dan temperatur lebur plastik

\begin{tabular}{cccc}
\hline $\begin{array}{c}\text { Jenis } \\
\text { Plastik }\end{array}$ & $\operatorname{Tm}\left({ }^{\circ} \mathrm{C}\right)$ & $\mathrm{Tg}\left({ }^{\circ} \mathrm{C}\right)$ & $\begin{array}{c}\text { Temperatur } \\
\text { Proses } \\
\text { Maksimal } \\
\left({ }^{\circ} \mathrm{C}\right)\end{array}$ \\
\hline PP & 168 & -5 & 80 \\
HDPE & 134 & -11 & 82 \\
LDPE & 330 & -115 & 260 \\
PA & 260 & 50 & 100 \\
PET & 250 & 70 & 100 \\
ABS & - & 110 & 85 \\
PS & - & 90 & 70 \\
PMMA & - & 100 & 85 \\
PC & - & 150 & 246 \\
PVC & - & 90 & 71 \\
\hline
\end{tabular}

Sumber: Jatmiko Wahyudi, dkk (2018)

\section{METODOLOGI PENELITIAN}

Proses pembuatan rancang bangun alat pengolahan sampah plastik menjadi bahan bakar minyak sintetis yang diberi nama "Aplas Jadul” adalah sebagai berikut:

1. Pencarian informasi melalui penelitian terdahulu yang sesuai dengan rancang bangun alat yang akan dibuat.

2. Menyiapkan konsep terbaik untuk rancang bangun alat.

3. Membuat rancang bangun alat disesuaikan dengan sumber pustaka.

Pembuatan rancang bangun alat pengolahan sampah plastik menjadi bahan bakar minyak sintetis ini menggunakan 
metode studi pustaka sebagai sumber informasi. Beberapa penelitian terdahulu yang telah berhasil mengembangkan alat serupa menggunakan listrik PLN juga digunakan sebagai sumber informasi terpercaya.

Perancangan alat ini disesuaikan dengan fungsi, karakteristik dan lingkungan dimana proses berlangsung. Alat pengolah sampah plastik ini terdiri dari reaktor utama yang terbuat dari plat besi berbentuk oval, kondensat sebagai pendingin uap, panel surya berserta komponen pendukungnya sebagai sumber utama energi untuk mengolah sampah plastik. Tabung utama merupakan tabung pemanas tempat sampah plastik diolah. Uap yang dihasilkan dari pemanasan diambil dan didinginkan melalui kondensat sampai cair dan menjadi minyak plastik yang kemudian ditampung di wadah penampungan.

\section{HASIL DAN PEMBAHASAN}

\section{A. PELAKSANAAN}

1. Persiapan Kegiatan

Persiapan kegiatan yang dilakukan meliputi:

a) Bermusyawarah dengan mitra (Bank Sampah Selo Beraksi) sekaligus bermusyawarah dengan Pemerintah Desa Pojok, Tawangsari, Sukoharjo sebagai pihak yang terlibat langsung dengan Bank Sampah Selo Beraksi.

b) Survei harga peralatan penunjang dan bahan habis pakai

c) Survei lokasi mitra bekerja

2. Pengadaan Alat dan Perlengkapan Kebutuhan

Tahap ini merupakan tahap lanjutan setelah tahap persiapan kegiatan terlaksana, yaitu berupa penyiapan alat serta perlengkapan kebutuhan untuk menunjang kesiapan proses pembuatan

3. Persiapan Produksi a) Mempersiapkan tempat dan fasilitas penunjang proses produksi di tempat produksi berlangsung

b) Pemasangan alat dan kelengkapan yang digunakan sebagai penunjang produksi

4. Proses Produksi

Tahapan yang harus dilakukan dalam tahap ini adalah:

a) Perancangan alat

Proses perancangan alat ini memerlukan beberapa tahapan yaitu:

- Membuat desain alat

- Pemilihan bahan sesuai kebutuhan dan sesuai standar alat

b) Pembuatan alat

Proses pembuatan alat ini memerlukan beberapa proses pengerjaan diantaranya:

- Pemotongan material/bahan baku

- Pengelasan

- Penggerindaan

- Pengamplasan

- Perangkaian

- Pengecetan

5. Uji Coba dan Penelitian

Setelah prosuk/alat berhasil dibuat, tahapam berikutnya adalah uji coba dan penelitian. Pada tahap ini alat diuji terhadap sampah-sampah plastik sekaligus memperhitungkan juga produktivitas alat tersebut.

6. Evaluasi Hasil Produk

Untuk meningkatkan kualitas terhadap alat yang dihasilkan, maka harus dilakukan beberapa evaluasi yaitu:

a) Kekuatan konstruksi

Melakukan uji coba terhadap alat agar dapat mengevaluasi kekuatan konstruksi dari alat yang diterapkan.

b) Model dan bentuk

Evalusi model dan bentuk dilakukan untuk mendapatkan detail bentuk dan ukuran yang sesuai dengan kondisi lapangan kerja.

Lingkungan Hidup dan Bencana 622 
c) Produktivitas alat

Evaluasi terhadap seberapa banyak bahan bakar minyak sintetis yang dihasilkan tiap kilogram sampah plastik dan berapa tegangan listrik yang harus ada untuk mengubah sampah plastik menjadi bahan bakar minyak sintetis.

7. Perbaikan Hasil Produk

Setelah melewati tahap evaluasi, tehapan berikutnya adalah melakukan perbaikan terhadap alat untuk mendapatkan hasil yang maksimal.

8. Penyusunan Laporan

Tahap akhir dari kegiatan ini adalah penyusunan laporan dari setiap analisa kegiatan yang telah dilaksanakan.

\section{B. JADWAL KEGIATAN}

\begin{tabular}{|c|c|}
\hline TAHAP & NAMA KEGIATAN \\
\hline $\begin{array}{l}\text { Bulan Ke } \\
1(\text { Minggu } \\
\text { ke } 1 \& 2)\end{array}$ & $\begin{array}{l}\text { Persiapan Kegiatan } \\
\text { 1. Musyawarah dengan mitra } \\
\text { 2. Survei harga peralatan } \\
\text { penunjang dan bahan habis } \\
\text { pakai } \\
\text { 3. Survei lokasi mitra bekerja }\end{array}$ \\
\hline $\begin{array}{l}\text { Bulan Ke } \\
\text { 1(Minggu } \\
\text { ke 3\&4) }\end{array}$ & $\begin{array}{l}\text { Pengadaan alat dan } \\
\text { perlengkapan kebutuhan }\end{array}$ \\
\hline $\begin{array}{l}\text { Bulan Ke } \\
\text { 2(Minggu } \\
\text { ke } 1 \& 2)\end{array}$ & $\begin{array}{l}\text { Persiapan Produksi } \\
\text { 1. Mempersiapkan tempat dan } \\
\text { fasilitas penunjang proses } \\
\text { produksi } \\
\text { 2. Pemasangan alat dan } \\
\text { kelengkapan }\end{array}$ \\
\hline $\begin{array}{l}\text { Bulan Ke } \\
\text { 2(Minggu } \\
\text { ke 3\&4) }\end{array}$ & $\begin{array}{l}\text { Proses Produksi } \\
\text { 1. Perancangan alat } \\
\text { 2. Pembuatan alat }\end{array}$ \\
\hline $\begin{array}{l}\text { Bulan Ke } \\
\text { 3(Minggu } \\
\text { ke } 1 \& 2)\end{array}$ & Uji Coba dan Penelitian \\
\hline
\end{tabular}

\begin{tabular}{|l|l|}
\hline $\begin{array}{l}\text { Bulan Ke } \\
\text { 3(Minggu } \\
\text { ke 3\&4) }\end{array}$ & Evaluasi Hasil Produk \\
\hline $\begin{array}{l}\text { Bulan Ke } \\
\text { 4(Minggu } \\
\text { ke 1\&2) }\end{array}$ & Perbaikan Hasil Produk \\
\hline $\begin{array}{l}\text { Bulan Ke } \\
\text { 4(Minggu } \\
\text { ke 3\&4) }\end{array}$ & Penyusunan Laporan \\
\hline
\end{tabular}

\section{Deskripsi Alat}

Perancangan mesin Aplas Jadul disesuaikan dengan fungsi, karakteristik dan lingkungan dimana proses berlangsung. Alat pengolah sampah plastik ini terdiri dari reaktor utama yang terbuat dari plat besi berbentuk tabung, kondensat sebagai pendingin uap, panel surya untuk menangkap cahaya matahari yang digunakan sebagai tempat penampungan sebagai sumber energi, dan botol sebagai penampung bahan bakar minyak sintetis. Tabung utama merupakan tabung pemanas tempat sampah plastik dipanaskan menggunakan tenaga listrik. Uap yang dihasilkan dari pemanasan diambil dan didinginkan melalui kondensat sampai cair dan menjadi bahan bakar sintetis yang kemudian ditampung di botol penampungan.Bahan baku (sampah plastik) yang digunakan didalam proses pirolisis merupakan bahan yang telah dilakukan pembersihan kotoran maupun air sehingga dianggap merupakan bahan baku kering (tidak mengandung kadar air didalam bahan baku tersebut).

\section{Pembahasan Desain Alat dan Cara Kerja Aplas Jadul \\ 1. Panel Surya}

Panel surya berfungsi sebagai sarana memperoleh energi guna mengoperasikan alat ini. Penyinaran matahari maksimal di Indonesia yang rata-rata 5 jam perhari 
ditampung dalam panel surya 200wp. Energi ini nantinya akan diteruskan ke rangkaian kedua yaitu rangkaian solar charge controller, modul speed controller, inverter, dan battery solar panel. Desain panel surya yang telah dibuat dapat dilihat dalam Gambar 1 yaitu sebagai berikut.

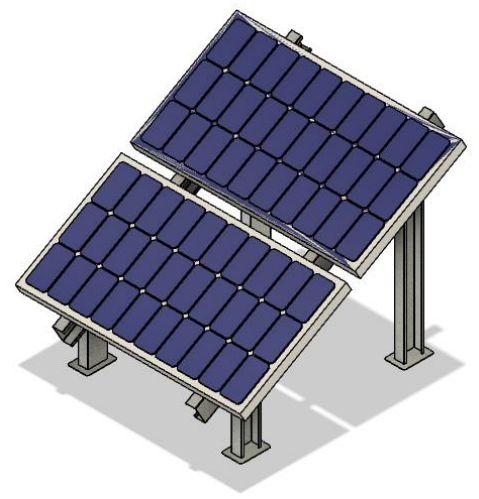

Gambar 1. Desain Panel Surya

2. Rangkaian Solar Charge Controller, Modul Speed Controller, Inverter, dan Battery Solar Panel

Desain yang kedua adalah rangkaian solar charge controller, modul speed controller, inverter, dan battery solar panel.Dalam rangkaian ini prinsip kerjanya cukup sederhana yaitu energi matahari yang ditangkap oleh panel surya kemudian diteruskan ke charger controller 30 ampere yang berfungsi mengatur arus untuk pengisian ke baterai, menghindari overcharging, dan overvoltage, mengatur arus yang dibebaskan atau diambil dari baterai agar baterai tidak full discharge, dan overloading, fungsi lain yaitu sebagai monitoring temperatur baterai. Setelah itu, energi diteruskan menuju Deep Cycle Gel Battery Solar Panel 12 ampere yang berfungsi untuk menyimpan energi yang diisi oleh aliran DC dari panel surya sekaligus untuk mengubah energi kimia menjadi energi listrik. Selanjutnya adalah inverter, inverter berfungsi untuk mengubah arus listrik searah (DC) menjadi arus listrik bolak balik (AC).

Dari inverter kemudian digabungkan dengan stopkontak, dari sinilah kemudian dirangkaikan lagi dengan modul speed control yang berfungsi untuk mengatur besar kecil arus listrik yang dialirkan menuju tong. Langkah selanjutnya adalah mengalirkan arus listrik tersebut di kawat nikelin yang sudah dibentuk sedemikian rupa. Kawat nikelin yang teraliri listrik ini kemudian dapat memanaskan tong stainless steel (prinsip kerja alat seperti kompor listrik). Desain rangkaian ini dapat dilihat pada Gambar 2 yaitu sebagai berikut.

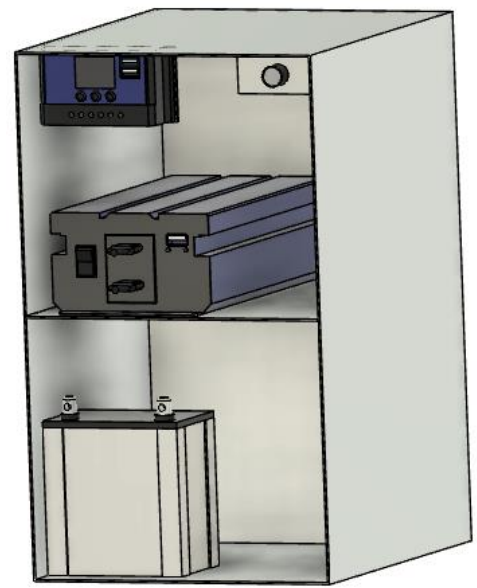

Gambar 2. Rangkaian Solar Charge

Controller, Modul Speed Controller,

Inverter, dan Battery Solar Panel

\section{Desain Tabung Pemanas}

Aplas Jadul menggunakan proses pirolisis. Pirolisis adalah dekomposisi termokimia bahan organik melalui proses pemanasan tanpa atau sedikit oksigen atau pereaksi kimia lainnya, dimana material mentah akan mengalami pemecahan struktur kimia menjadi fase gas. Dalam prosesnya, sampah plastik yang telah dimasukkan akan dipanaskan menggunakan kawat nikelin 
yang sumber panasnya berasal dari panel surya. Panas ini nantinya akan meleburkan sampah plastik sehingga akan membentuk gas yang terkumpul di dalam tabung lalu menuju ke proses kondensasi. Tabung pemanas ini dilengkapi dengan roda dibawahnya sehingga memudahkan apabila akan dipindah-pindah tempat. Desain tabung pemanas dilihat dari sudut pandang bawah tabung dapat dilihat pada Gambar 3, sedangkan tabung yang dibelah dua dapat dilihat pada Gambar 4 yaitu sebagai berikut.

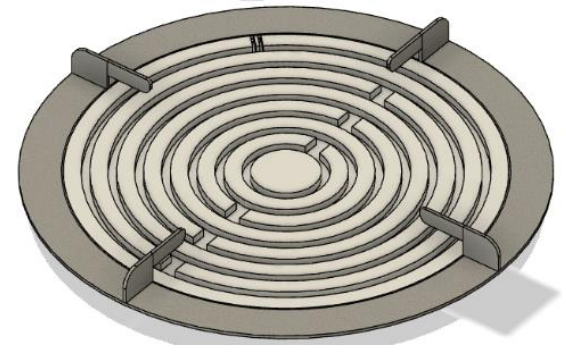

Gambar 3. Bagian Bawah Tabung Pemanas Tempat Kawat Nikelin

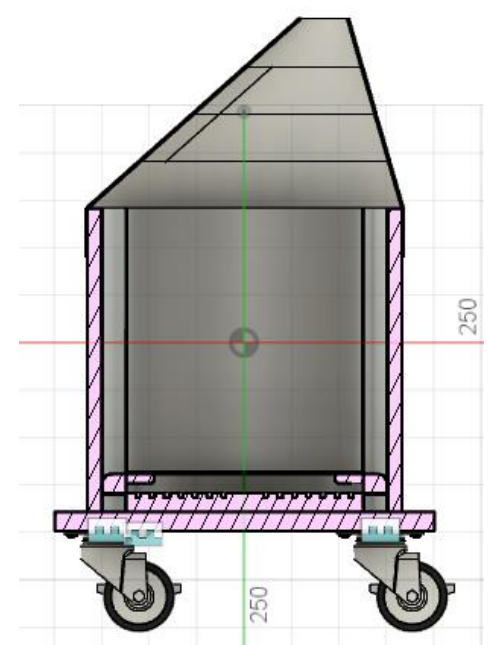

Gambar 4. Tabung Pemanas yang Dibelah Menjadi Dua

4. Desain Bagian Kondensasi

Plastik yang dipanaskan akan menguap dan uap tersebut akan mengalir melalui pipa aluminium. Di dalam pipa aluminium tersebut akan mengalami kondensasi dimana uap hasil pemanasan sampah plastik akan berubah menjadi bahan bakar minyak dikarenakan adanya air mengalir yang mendinginkan uap tersebut. Setelah melalui proses kondensasi bahan bakar minyak tersebut akan ditampung dalam wadah. Desain proses kondensasi ini dapat dilihat pada Gambar 5 yaitu sebagai berikut.

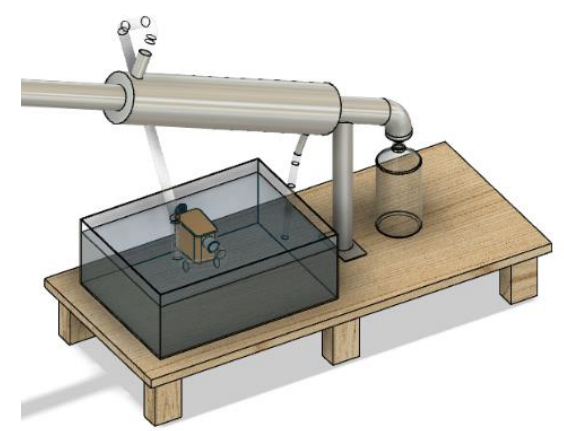

Gambar 5. Rangkaian Proses Kondensasi

\section{Desain Mesin "Aplas Jadul”}

Seluruh rangkaian desain-desain diatas dirangkai dalam satu kesatuan yang tepat yaitu menjadi mesin Aplas Jadul yang dapa dilihat pada Gambar 6 yaitu sebagai berikut.
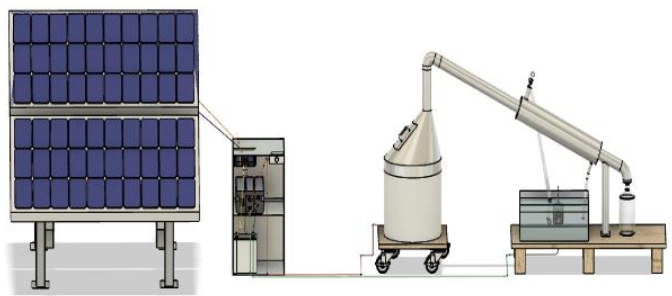

Gambar 6. Desain Aplas Jadul 


\section{KESIMPULAN}

Indonesia sudah mengalami krisis sampah plastik dan harus ada solusi yang tepat untuk menangani permasalahan ini, dan kami menawarkan mesin APLAS JADUL yang mengubah sampah plastik menjadi bahan bakar minyak alternatif yang ramah lingkungan sehingga berdampak baik bagi lingkungan dan kehidupan masyarakat. Tulisan ini membahas tentang desain mesin pengubah sampah plastik yang diberi nama APLAS JADUL. Kelebihan dari alat ini adalah menggunakan tenaga surya sehingga ramah lingkungan dan menghemat energi panas bumi seperti gas elpiji. Pengolahan sampah plastik menjadi bahan bakar minyak alternatif tentunya menjadi solusi yang tepat untuk mendaur ulang sampah plastik tanpa menjadikannya plastik kembali.

Keuntungan lain yang dapat diperoleh adalah kesejahteraan masyarakat Desa Pojok, Tawangsari, Sukoharjo, karena dapat mengganti bahan bakar minyak biasa menjadi bahan bakar minyak alternatif ini untuk menjalankan mesin traktor, mesin diesel, alat pemotong rumput, dan kendaraan bermotor. Oleh karena itu, keberadaan mesin ini akan menguntungkan lingkungan dan masyarakat Indonesia.

\section{REFERENSI}

[1] Eko Prihatmoyo, Pandam, dkk. Rancang Bangun Mesin Destilator Pengubah Limbah Plastik Menjadi Minyak. Proceedings Conference on Design Manufacture Engineering and its Application. e-ISSN No.2654-8631: 106.

[2] Hakim, Muhammad Fahmi. 2017. Perancangan Rooftop Off Grid Solar Panel Pada Rumah Tinggal Sebagai Alternatif
Sumber Energi Listrik. Jurnal Dinamika DotCom. 8 (1): 6.

[3] Hasan, Hasnawiya. 2012. Perancangan Pembangkit Listrik Tenaga Surya di Pulau Saugi. Jurnal Riset dan Teknologi Kelautan (JRTK). 10 (2): 170171.

[4] Heri, Junial. Pengujian Sistem Pembangkit Listrik Tenaga Surya Solar Cell Kapasitas 50wp. Hal 50.

[5] Irwansah, Muhammad dan Didi Istardi. 2013. Pompa Air Aquarium Menggunakan Solar Panel. Jurnal Integrasi. 5 (1): 86.

[6] Landi, Faufan dan Arijanto. 2017. Perancangan dan Uji Alat Pengolah Sampah Plastik Jenis LDPE (Low Density Polyethylene) Menjadi Bahan Bakar Alternatif. Jurnal Teknik Mesin S-1. 5 (1):35 .

[7] Nandika, Reza dan Pamor Gunoto. 2018.Pemanfaatan Sel Surya 50 Wp Pada Lampu Penerangan Rumah Tangga di Daerah Hinterland. Sigma Teknika. 1 (2): 189.

[8] Nasution, Reni Silvia. 2015. Berbagai Cara Penanggulangan Sampah Plastik. Journal of Islamic Science and Technology. 1 (1): 97.

[9] Raban, Raksa, dkk. 2015. Desain dan Implementasi Charger Baterai Portable Menggunakan Modul Ic X16009el Sebagai Boost Converter Dengan Memanfaatkan Tenaga Surya. e-Proceeding of Engineering. 1 (2): 1902. 
[10] Rezky Ananda, Eka, dkk. 2018. Pembuatan Alat Pengolah Limbah Cair Dengan Metode Elektrokoagulasi Untuk Industri Tahu

Kota Samarinda. Jurnal Teknik Terpadu. 6 (1): 58 .

[11] Wardi, I Nyoman. 2011. Pengelolaan Sampah Berbasis Sosial
Budaya: Upaya Mengatasi Masalah Lingkungan di Bali. Jurnal Bumi Lestari. 11 (1): 167.

[12] Wahyudi, Jatmiko, dkk. 2018. Pemanfaatan Limbah Plastik Sebagai Bahan Baku Pembuatan Bahan Bakar Alternatif. Jurnal Litbang. 14 (1): 60. 